\title{
Technical report for the Higher Technological Institute of the Sierra region in matters of productivity, for the generation of an improvement model
}

\section{Informe técnico para el instituto tecnológico superior de la región sierra en materia de productividad, para la generación de un modelo de mejoramiento}

PÉREZ-GÓMEZ, Gerardo Ernesto†*, PÉREZ-PÉREZ, Iris Cristel, ELISEO-DANTÉS, Hortensia and LÓPEZ-ANZUREZ, Omar Alejandro

CONACYT / TecNM campus Villahermosa, Mexico.

ID $1^{\text {st }}$ Author: Gerardo Ernesto, Pérez-Gómez / ORC ID: 0000-0002-3681-3594, CVU CONACYT ID: 959329

ID $1^{\text {st }}$ Co-author: Iris Cristel, Pérez-Pérez / ORC ID: 0000-0003-3120-5597, Researcher ID Thomson: G-1891-2018, PubMed Autor ID: 4153742f278c38045ef7e6c0e83c476d4208, CVU CONACYT ID: 843577

ID $2^{\text {nd }}$ Co-author: Hortensia, Eliseo-Dantés / ORC ID: 0000-0003-4006-4669, Researcher ID Thomson: F-6749-2018, PubMed Autor ID: 6eb3adfd69824484b018f668c2670f109f08, CVU CONACYT ID: 411079

ID $3^{\text {rd }}$ Co-author: Omar Alejandro, López-Anzurez / ORC ID: 0000-0002-2769-4087, CVU CONACYT ID: 1003678

DOI: $10.35429 / E J S .2021 .15 .8 .10 .15$

Received July 15, 2021; Accepted December 30, 2021

Abstract

Productivity is essential for all organizations, especially in current times where companies are still suffering the drastic changes given by the Covid -19 pandemic, this transformation has provided new areas of opportunity around the world, generating new techniques, jobs and This is the case of the present investigation that focuses on the realization of a technical report in the Institutions of Higher Education of the public sector, taking as a reference the Higher Technological Institute of the Sierra Region. This report is carried out through a systemic and comprehensive approach, considering the use of the Comprehensive Technical Productivity Assessment tool (TIEP) that integrates within its application the evaluation of 10 priority elements to achieve productivity and therefore the quality of organizations. It should be noted that the information that integrates the tool and the elements is taken directly from the experts linked in the context of the study. It is of great importance to mention the participation of the personnel who collaborated in the compilation of the information, as well as the experts who advised to be able to integrate a comprehensive scheme of the organizational scenario.

Productivity, Institute of higher education, Comprehensive approach

Citation: PÉREZ-GÓMEZ, Gerardo Ernesto, PÉREZ-PÉREZ, Iris Cristel, ELISEO-DANTÉS, Hortensia and LÓPEZANZUREZ, Omar Alejandro. Technical report for the Higher Technological Institute of the Sierra region in matters of productivity, for the generation of an improvement model. ECORFAN Journal-Spain. 2021. 8-15:10-15.
Resumen

La productividad resulta fundamental para todas las organizaciones, sobre todo en tiempos actuales donde las empresas sufren todavía los cambios drásticos dados por la pandemia por Covid -19, esta transformación ha brindado nuevas áreas de oportunidad en todo el mundo, generando nuevas técnicas, empleos y conocimientos.Este es el caso de la presente investigación que se centra en la realización de un informe técnico en las Instituciones de Educación Superior del sector público, tomando como referencia el Instituto Tecnológico Superior de la Región Sierra. Este informe se lleva a cabo a través de un enfoque sistémico e integral, considerando el uso de la herramienta Técnica Integral de Evaluación de la Productividad (TIEP) que integra dentro de su aplicación la evaluación de 10 elementos prioritarios para lograr la productividad y por ende la calidad de las organizaciones. Cabe señalar que la información que integra la herramienta y los elementos, es tomada directamente de los expertos vinculados en el contexto del estudio. Es de gran importancia mencionar la participación del personal que colaboró para la recopilación de la información, así como los expertos que asesoraron para poder integrar un esquema integral del escenario organizacional.

Productividad, Instituto de educación superior, Enfoque integral

\footnotetext{
* Correspondence to Author (E-mail: gerardoernesto52@gmail.com)

$\dagger$ Researcher contributing first author.
} 


\section{Introduction}

Higher education is a key element to improve the development and productive capacities of the State, as well as to propitiate a better cultural and political level. The Technological Institutes promote the development of man in harmony with the environment, with others and with himself, where the recovery and future projection of the cultural heritage in its different fields and dimensions acquires fundamental importance.

Without quality higher education, it will not be easy to break the vicious circle of exclusion or to offer young people more and better opportunities and higher levels of wellbeing. A quality educational offer is also an indispensable means to achieve a more advantageous insertion of Mexico in the knowledge economy and in the value chains of global competitiveness.

Efforts to improve the quality of services provided by educational institutions have been underway for at least two decades. Among the various measures implemented, programs for institutional strengthening, the professionalization of academic personnel, the formation and strengthening of academic bodies and the integration of research networks stand out.

The measurement of processes allows identifying the main problems in a specific way, in such a way that provides better understanding at the time of locating areas of opportunity and improvement, which is why productivity is a key pillar in any organization with which an integral approach that benefits all stakeholders is determined, analyzing each of the variables of the context.

The development of this project is determined by the need to evaluate productivity in the Instituto Tecnológico Superior de la Región Sierra, in order to maintain a good productive level and to know the current situation of the organization, through the application of the tool "Integral Technique of Productivity Evaluation" in order to analyze the ten elements that every organization must take into account for the improvement of the system.

\section{Description of the method}

In order to give continuity to this productivity improvement, the application of a tool called: Integral Evaluation Technique for Productivity (TIEP), which identifies in what way the variables of the context influence the ten elements that every organization should have to integrate the knowledge and development of the organization, these elements are essential for the integral knowledge of the company and integrate a series of general and specific aspects that denote the productive scope of the company.

Elements:

\begin{tabular}{|l|}
\hline 1. Conceptual approach of the company. \\
\hline 2. Knowledge of the processes. \\
\hline 3. Social scope of the organization. \\
\hline 4. Planning administration. \\
\hline 5. Management participation. \\
\hline 6. Organizational creativity and innovation. \\
\hline 7. Knowledge of customers. \\
\hline 8. Technological development. \\
\hline 9. Macroeconomic knowledge. \\
\hline 10. Integral development of human resources. \\
\hline
\end{tabular}

The Integral Evaluation Technique for Productivity (TIEP) is a tool that gives us the security of being able to evaluate ten fundamental elements that every organization must have, with this generate a concrete measurement through a qualitative and quantitative analysis that relates the elements with the variables of the context; Environmental, Cultural, Economic, Social, Political, Technological, that could influence the productivity of the institute.

It is considered that the evaluation is performed in each of the departments that make up an organization and can be segmented by a group of departments, this is done personally so that the interviewer can engage in a conversation that integrates questions with which to qualify at its discretion how the variables influence on each of the elements and their relationship.

\section{Analysis based on the method}

The study of productivity using the Integral Productivity Evaluation Technique tool (Dantés, 2021), allowed obtaining results of the institution with a view to the application of an integral approach, analyzing the different elements that every organization must integrate in its work areas and identifying the incidence of the variables of the context on these, in order to determine the productive level of the institution.

PÉREZ-GÓMEZ Gerardo Ernesto, PÉREZ-PÉREZ, Iris Cristel, ELISEO-DANTÉS, Hortensia and LÓPEZ-ANZUREZ, Omar Alejandro. Technical report for the Higher Technological Institute of the Sierra region in matters of productivity, for the generation of an improvement model. ECORFAN Journal-Spain. 2021 
The present study will focus on the study of the academic sub-direction of the Instituto Tecnologico Superior de la Región Sierra, where the following departments were taken as reference for its study:

\section{Academic Direction.}

\section{Academic Subdirection.}

Subdirection of Graduate Studies.

Subdirección de Servicios Admisnistrativos (Administrative Services).

Head of the Management Engineering Division. The application of 5 instruments will be considered, one in each of the above mentioned departments to analyze the 10 elements that every organization should integrate in its organization for the control and improvement of productivity.

\section{Results}

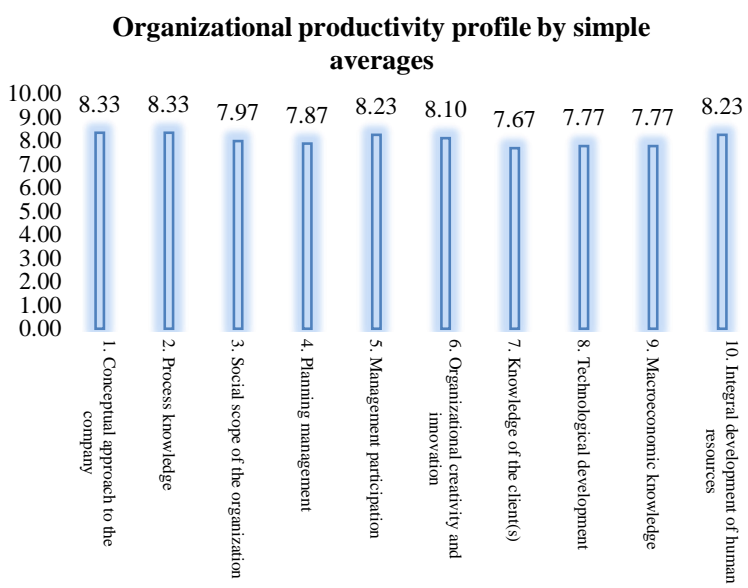

Graphic 1 Productivity profile of the organization Source: Author's elaboration, 2021
The integral graph of the organization's productivity profile shows the relationship of each of the departments and is summarized in the following, the departments are at a stable level given the interpretation of the graph, however there is the impact of the variables on each of the elements, this greatly influences the results and as can be seen in the graph the weight of the variables in the elements is remarkable, especially there are more notable points for the variables; economic, environmental, technological and social. The elements with lower scores; knowledge of customers, technological development and macroeconomic knowledge, represent the incidence of the variables as well as a performance with areas of opportunity, that through the design of an improvement model, it is possible to identify those points that would concretize and help to raise the score of the organization.

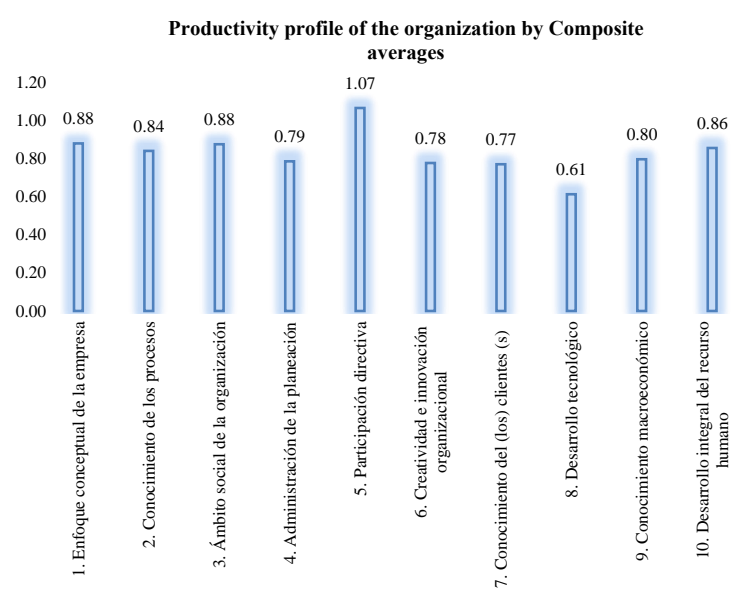

Graphic 2 Productivity profile of the organization Source: Author's elaboration, 2021

In the following graph we can see more clearly where this score is leaning, which is one of the red lights for the institution. Technological development is of great importance for all organizations and even more so for higher education institutions, since this is where the knowledge comes from and the generation of trained personnel to perform their activities in the industry, which is why the measurement showed the lack of implementation of technological systems that improve the academic performance of students and teachers in their work.

Similarly, there is a better score on the element "knowledge of customers", this despite having a low score, is due to the integration of one of the departments that scored low on this element, however in most of these there is a total and integrated understanding of customers, thus concluding that the impact of the variables influences the time to obtain the results. 


\section{Proposal}

The Instituto Tecnológico Superior de la Región Sierra is an organization committed to the development of professionals in the industry, that is why by measuring its academic areas we were able to determine that it is at a stable level, given the scores obtained in the different areas, however we found incidence of the variables in the elements evaluated in each department, determining that the impact of these greatly influences the performance and achievement of the objectives.

It is found that the organization does not have a department in charge of environmental issues, a procedure or a guideline to achieve certification to improve processes and provide greater presence in higher education institutes in the state of Tabasco. It should be noted that in order to integrate this into the system, it is necessary to implement training to raise awareness of environmental issues in the different areas.

Similarly, technological development is a highlight, due to the lack of equipment to improve the development of knowledge in students, this does not mean that the institute does not have equipment, but it has very well equipped laboratories, but analyzing the constant changes in the present given by technological advances and the presence of a confinement by the health contingency generates new needs in the labor market, which is why the implementation of new equipment and technological services would improve the productivity of the organization.

Finally, the integration of a quality culture that benefits the system in an integral way, where the elements that determine the tool, are used with its totality in all the areas, which will look for a common goal, to be a productive company.

\section{Productivity improvement model}

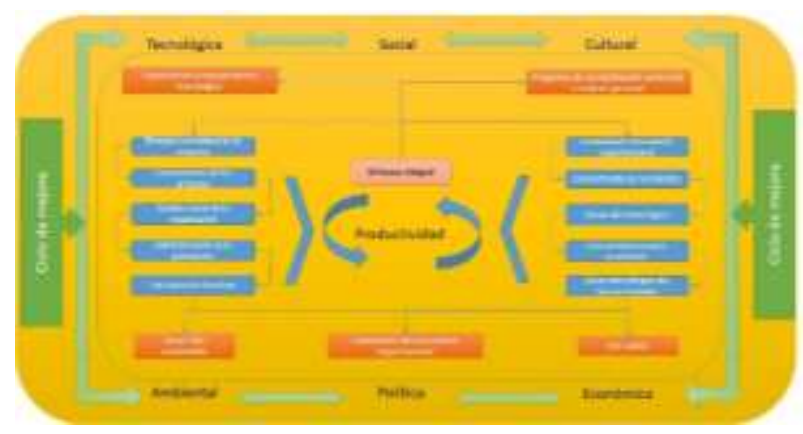

Figure 1 Productivity improvement model Source: Author's elaboration, 2021

In the model presented, it is possible to visualize the representation of the organization as a system with an integral approach where all areas of the institution work inside and outside. In the same way, the elements of the TIEP tool are integrated, since through these it is possible to analyze the departments and the incidence of the variables, from this it is considered that the variables of the context significantly influence the results of the organization and it is determined the integration of improvement cycles throughout the company. The impact of specific variables shows areas of opportunity that will benefit the organization as a whole.

Training and technological equipment.

At this point it is assumed that the organization needs new technological equipment to improve the academic performance of students in the industry, this given the emerging changes in the present and technological progress, likewise it is proposed to train the staff so that any subject or activity that requires it, there is a human resource that knows how to perform the use of machinery.

Generation of an organizational culture.

Thinking about the generation and implementation of an organizational culture is due to the lack of certain aspects in the institution, since the organizational culture can facilitate the implementation of strategies if there is a strong coherence between the two or, on the contrary, prevent or delay their implementation. If we accept the premise that business strategy, in addition to leading the company towards the achievement of certain economic objectives, serves as a guide in its constant quest to improve its performance, it can be deduced, therefore, that culture can and does influence the results of the company's activity.

Environmental awareness program. 
This program will serve to improve the entire company, not only internally, but also externally, since it will raise awareness of those aspects that were not so relevant in the location of the institution, as well as in the region. Strategies that benefit the environment will be implemented, school programs that provide support to localities through the development of projects that integrate this sensitivity to environmental care, thus generating an environmental culture in the organization.

Sustainable development.

Sustainable development is that development that is capable of satisfying current needs without compromising the resources and possibilities of future generations. Thus, keeping in mind objectives with a view to the future will benefit the institution, as well as providing an example to the students.

\section{ISO 14001.}

The international standard ISO 14001: 2015 Environmental Management Systems, provides specific guidelines through a set of standards covering aspects of the environment, products and organizations, when implemented provides better information management and a high degree of quality. This Environmental Management Systems (EMS) standard enables companies to demonstrate that they are responsible and committed to protecting the environment. And when implemented in the organization denotes a high degree of commitment.

\section{Acknowledgements}

This work is the result of the effort and dedication of a work team, who throughout the development gave their support to the author and collaborators.

This document arises as an exploratory research for a master's degree subject called Measurement and Improvement of Productivity.

Thanks are given to the colleagues involved in this research as well as to the advice provided in order to obtain feedback on the work.

\section{Conclusions}

As a conclusion to this work it is determined that the Instituto Tecnológico Superior de la Región Sierra is in a stable level, however it is demonstrated that the variables of the context and its incidence in the elements can influence at any given moment in the results obtained.

It is suggested that the institution initiate changes or improvements to the system as soon as possible, since this will greatly benefit the personnel as well as the organizational performance, providing a better service based on quality and productivity.

It is recommended to create an environmental committee, which will be responsible for seeking the necessary measures to raise the awareness of all personnel, as well as the implementation of international standards, since these will provide specific guidelines that will help in the search for continuous improvement. In the same way, training and technological equipment is sought, that is why a survey on new technologies in the world will provide support when selecting the desired equipment for the corresponding divisions, it should be noted that the use of software today and for contingency reasons have been crucial for the management and business continuity, which is why programs should also be implemented to help materialize the knowledge that teachers provide to the student community.

The materialization of the model can be materialized in the application of the same, taking as a starting point the research given the present, being internal aspects of the organization and to a large extent none affect the processes of this, you can continue with the activities in its normality, however it is necessary to appoint staff to integrate a committee to carry out the recommendations mentioned, as well as periodic evaluations using the TIEP tool, as it ensures concrete and stable results that seek the full benefit of organizations.

\section{Referencias}

Dantés, H. E. (2021). Técnica Integral de Evaluación de la Productividad. Villahermosa , Tabasco, México.

Instituto Tecnológico Superior de la Región Sierra. (2021). ITSS. Obtenido de http://www.itss.edu.mx/ 
Méndez, M. I. (Julio de 2012). Manual de Organización del Instituto Tecnológico Superior de la Región Sierra. Teapa, Tabasco, México.

Subsecretaría de Planeación, E. y. (Diciembre de 2017). Secretaría de Educación Pública. Obtenido https://www.gob.mx/cms/uploads/attachment/fi le/314717/E010_Servicios_de_Educacio_n_y_p osgrado_-_Diagno_stico_2017.pdf

UNESCO. (14 de Septiembre de 2020). Obtenido

https://www.iesalc.unesco.org/2020/09/14/laeducacion-superior-no-es-una-carga-sino-unapieza-clave-para-enfrentar-la-crisis-francescpedro/\#.YOJezuhKjIU 